\title{
Functional and technological properties of food nanoadditives based on double oxide of divalent and trivalent iron
}

\author{
Iryna Tsykhanovska ${ }^{1}$, Victoria Evlash ${ }^{2}$, \\ Oleksandr Aleksandrov ${ }^{1}$, Lidiia Tovma ${ }^{3}$
}

1 - Ukrainian Engineering Pedagogics Academy, Kharkiv, Ukraine

2 - Kharkiv State University of Food Technology and Trade, Kharkiv, Ukraine

3 - National Academy of the National Guard of Ukraine, Kharkiv, Ukraine

Keywords:

Retention

Water

Fat

Iron oxide,

Nanoassociates

Article history:

Received

12.12.2019

Received in revised

form 25.03.2020

Accepted

30.06.2020

Corresponding

author:

Iryna Tsykhanovska

E-mail:

cikhanovskaja@

gmail.com

DOI:

$10.24263 / 2310$ -

1008-2020-8-1-5

\section{Abstract}

Introduction. The water and fat-retaining abilities of food nanoadditives based on the double oxide of divalent and trivalent iron $\left(\mathrm{Fe}_{3} \mathrm{O}_{4}\right)$ known as Magnetofood were studied.

Materials and methods. Model systems: starch + magnetofood, egg white+magnetofood, fat + magnetofood. Water and fat retention properties were examined with energy dispersive X-ray (EDX) and IR-Fourier spectroscopies (FTIR). The mass fraction of bound and free moisture was determined using the indicator method (IM) and differential thermal analysis (DTA).

Results and discussion. The ability of $\mathrm{Fe}_{3} \mathrm{O}_{4}$ food additive nanoparticles is noted to form electrostatic complexes with macromolecular compounds of food systems (proteins, carbohydrates, lipids) - quite stable structures such as "clusters", "clathrates", "cavitates", "supramolecular associates". This property promotes binding and retention of water and fat. Hydrophilic contacts of solvated $\mathrm{Fe}_{3} \mathrm{O}_{4}$ nanoparticles with water dipoles, molecules of proteins and polysaccharides (carbohydrates) increase the stability of polyphasic systems.

An offset of the IR spectra of the maximum absorption of the $\mathrm{Fe}-\mathrm{O}$ bond to the high-frequency region by $(57 \pm 2) \mathrm{cm}^{-1}$ in comparison with the experimental sample of pure food additive Magnetofood $-\mathrm{Fe}_{3} \mathrm{O}_{4}$ (FAM) indicates the chemical interaction of FAM iron cations with molecules of macromolecular compounds (starch, egg white, fat).

The chemical composition of model systems of macromolecular compounds with FAM was determined in energy dispersive X-ray studies. For pure FAM, particles of Fe comprised $75.5 \% ; \mathrm{O}-24.5 \%$; for the additive particles coated with egg white - Fe 44.7\%; O 26.9\%; C 21.4\%; N 5.9\%; S 1.1\%; for the additive particles coated with starch - Fe 41.7\%; O 35.7\%; C 22.6\%; for the additive particles coated with linoleic acid - Fe 45.6\%; O 34.7\%; C $19.7 \%$; for the additive particles coated with sunflower oil - Fe $39.7 \%$; O $36.7 \%$; C $23.67 \%$.

The ratio of bound and free moisture in solvated FAM: $50.5-$ $51.6 \%$ of water comprise bound moisture and 48.4-49.5\% constitute free, osmotic (swelling water) and physico-mechanical water of the total amount.

Conclusions. For the first time, models of interaction of $\mathrm{Fe}_{3} \mathrm{O}_{4}$ nanoparticles with water, proteins, fats, and carbohydrates have been suggested for substantiating the mechanisms of water and fat retention of food additive nanoparticles based on double oxide of divalent and trivalent iron. 


\section{Introduction}

The most important functional and technological properties of food raw materials and food ingredients, which determine the course of technological processes and the quality of finished products, are water-retaining capacity (WRC) and fat-retaining capacity (FRC).

Mineral compounds [1]; special compositions of DSM enzymes [2]; biologically active substances of vegetable, fruit and herbal supplements [3-6]; various polysaccharides (citrus fibers; hydrocolloids of plant origin, cellulose esters) [7-10]; powders based on dairy and egg products [11-14]; functional ingredients derived from industrial by-products (leather, hooves, feathers, offal, seeds, bran, whey, etc.) [15, 16]; bioadditives based on wheat [17], soybeans, chickpeas, enzymes, microalgae, etc. [18-21] are used to increase the WRC of raw materials and food systems. The disadvantages of these additives are their narrow orientation and lack of complex action.

Food additives of various origins are used to improve the FRC of lipid-containing systems. They are nanopowders (silver, oxides of iron, magnetite, titanium and silicon dioxide, zinc oxide) [22-25]; modifications of magnetite nanoparticles with oleic acid [26]; modifications of nanoparticles of iron oxides and gyroxides with higher fatty acids and fats [27]. An adequate FRC of nanometer food additives is associated with high dispersion - this allows not only to bind free fats, but also to keep them on the surface of nanoparticles during cooking, as well as with the good availability of numerous hydrophobic areas [22-27].

An analysis of the scientific papers [1-27] revealed insufficiency of data on substantiating water and fat retention capacities of food nanoadditives, in particular, nanoparticles of food nanoadditives based on double oxide of divalent and trivalent iron ("Magnetofood") in food systems. "Magnetofood" food nanoadditives $\left(\mathrm{Fe}_{3} \mathrm{O}_{4}\right)$ are marked with a wide range of functional and technological properties (structural, stabilizing, sorption, etc.) and promising technological applications [23, 28-35].

Therefore, there is a need to study the water and fat retention capacities of the "Magnetofood" food nanoadditive.

The aim of the research is to study the water and fat retention of food additives based on double oxide of divalent and trivalent iron known as "Magnetofood" (FAM).

To achieve this goal, the following tasks are set:

- Analyse the mechanism of interaction between macromolecular compounds (starch, egg white, higher fatty acid, fat) and FAM nanoparticles using FTIR spectroscopy;

- Establish the chemical composition of the experimental samples of FAM - pure FAM, samples covered with starch / egg white / higher fatty acid (linoleic) / sunflower oil applying the method of energy-dispersive X-ray spectroscopy;

- Determine the ratio of bound and free moisture in solvated FAM using the indicator method and differential thermal analysis.

\section{Materials and methods}

\section{Materials}

Research object: water retention and fat retention capacities of powdered ingredients in food raw materials, namely nanoparticles of food additives based on iron oxides known as "Magnetofood" - $\mathrm{Fe}_{3} \mathrm{O}_{4}$ (FAM). 
Research subject:

- "Magnetofood", food nanoadditive based on iron oxides - $\mathrm{Fe}_{3} \mathrm{O}_{4}$ (FAM): highly dispersed nanopowder of brown or black colour with a particle size of $70-80 \mathrm{~nm}$. According to its chemical composition, "Magnetofood" is a double oxide of iron ( $\mathrm{FeO} \cdot \mathrm{Fe}_{2} \mathrm{O}_{3}$ or $\mathrm{Fe}_{3} \mathrm{O}_{4}$ ) obtained by the method of chemical coprecipitation from aqueous solutions of salts of divalent and trivalent iron in an alkaline medium[36,37];

- Model systems: "starch+magnetofood", "egg white+magnetofood", "linoleic acid+magnetofood", "sunflower oil+magnetofood": a suspension of FAM in $3 \%$ starch solution was obtained by introducing a portion of FAM into 3\% polysaccharide solution at $(55-60){ }^{\circ} \mathrm{C}$ while constant stirring $\mathrm{n}=(2.0-2.2) \mathrm{s}^{-1}$ for $(5-$ 7) $\times 60 \mathrm{~s}$ with subsequent cooling of the mixture to a temperature of $(18-20){ }^{\circ} \mathrm{C}$ and constant stirring $\mathrm{n}=(2.0-2.2) \mathrm{s}^{-1}$ [32]. A suspension of FAM in a 3\% solution of egg white was obtained by introducing a calculated amount of FAM into a 3\% solution of egg white at a temperature of $(18-20)^{\circ} \mathrm{C}$ while constant stirring $\mathrm{n}=(2.0-2.2) \mathrm{s}^{-1}$ for $(3-$ $5) \times 60 \mathrm{~s}$ followed by seasoning for (5-7) $\times 60 \mathrm{~s}$ [33]. Fatty suspensions of FAM were obtained by peptizing the calculated amount of FAM in oil (linoleic acid) at a temperature of $(45-50){ }^{\circ} \mathrm{C}$ (rational ratio of components - FAM:fat $=50 \mathrm{wt} . \%: 50 \mathrm{wt} . \%$, i. e. $2.5 \mathrm{~g}$ of suspension contains $1.25 \mathrm{~g}$ FAM) under condition of thorough stirring $\left(\mathrm{n}=2.0-2.2 \mathrm{~s}^{-1}\right)$ for $(3-4) \times 60 \mathrm{~s}$, followed by cooling the mixture to a temperature of (1820) ${ }^{\circ} \mathrm{C}$ and constant stirring $\mathrm{n}=(2.0-2.2) \mathrm{s}^{-1}[34,35,38,39]$.

\section{Research methods}

Fourier-transform infrared spectroscopy (FTIR). The vibrational spectra of the test samples were obtained using Fourier Transform Infrared Spectrometer (FTIR) Bruker Tensor 37 (Germany), controlled by the OPUS software package with standard calibration capabilities within the frequency range of $(4000-400) \mathrm{cm}^{-1}$ in the absorption format (Fourier spectra of samples were taken in $\mathrm{KBr}$ tablets) [25, 26, 36, 37].

Energy dispersive X-ray spectroscopy (EDX). To determine the chemical composition of the test samples used a scanning electron microscope JSM-820 (JEOL) with the prefix EDX. X-ray spectra were obtained by bombarding the test samples with electrons using an acceleration voltage of $20 \mathrm{kV}$ (according to the lines of the characteristic spectra of Iron, Carbon and Oxygen). Establishment of the elemental composition of the experimental samples was performed by analysis of the obtained spectra of characteristic X-rays [26, 27, $36,37]$.

Algorithm for determining the mass fraction of bound and free moisture by the indicator method according to the methods of Knyaginichev and Ermakova [42] and with the differential thermal analysis (DTA) [43]

The idea of the refractometric method is to determine the difference in dry matter (DM) between the indicator-solution of sugar and FAM solvated in sugar solution [42].

Bound moisture was calculated using the following formula (1):

$$
\mathrm{X}=\mathrm{B} \times\left(\mathrm{b}_{2}-\mathrm{b}_{1}\right) / \mathrm{P} \times \mathrm{b}_{2} \text {, }
$$

where $\mathrm{X}$ is the amount $(\mathrm{g})$ of bound water per $1 \mathrm{~g}$ of dry matter $(\mathrm{DM}) ; \mathrm{b}_{1}$ and $\mathrm{b}_{2}-$ initial and final concentrations of sucrose solution, $\%$; B - mass of $20 \mathrm{~cm}^{3} 10 \%$ sucrose solution, $\mathrm{g}$; P portion of dry matter (DM), g. 
Free moisture was calculated by formula (2):

$$
\mathrm{Y}=\left(\mathrm{C}_{0}-\mathrm{C}_{1}\right) \times \mathrm{m} \times 100 / \mathrm{C}_{1} \times \mathrm{g} \times \mathrm{W},
$$

where $\mathrm{Y}$ is the content of free water, $\%$ of the total content; $\mathrm{C}_{0}-$ initial concentration of sucrose solution, $\% ; \mathrm{C}_{1}-$ final concentration of sucrose solution, $\% ; \mathrm{m}-$ mass of the initial sucrose solution, $\mathrm{g} ; \mathrm{g}$ - sample weight, $\mathrm{g} ; \mathrm{W}$ - total water content in $1 \mathrm{~g}$ of sample, $\mathrm{g}$.

Differential thermal analysis (DTA) [43]. Thermographic determinations were carried out using derivatograph Q-1500 D by "MOM" (Hungry) for a sample weight of $0.5 \mathrm{~g}$ in the following modes of taking derivatograms: sensitivity of DTA galvanometer -250 , DTG galvanometer -500 , TG galvanometer -500 , heating temperature change rate $-4^{\circ} \mathrm{C} / 60$ s. The dependences of the change rate for mass $\alpha$ on the temperature $T$ were built based on the change curve $T G$ which corresponds to the process of dehydration and the temperature curve $T$. To do this, every $5{ }^{\circ} \mathrm{C}$ the researchers fixed a change in mass of the sample as well as the total mass fraction of moisture, which was determined by the $T G$ curve, at the end of the crystallization process. The change rate for mass $\alpha$ was calculated using the following formula (3):

$$
\alpha=\nabla m_{T} / m \text {, where } \alpha-\text { rate of change of mass, }
$$

where $\nabla m_{T}$-change in mass of the sample at a temperature $\mathrm{T}, 10^{-3} \mathrm{~g}$;

$m$ - total mass fraction of moisture contained in the sample, $10^{-3} \mathrm{~g}$

\section{Results and discussion}

\section{Chemical interaction of "Magnetofood" nanoparticles (MNP) with the main food ingredients}

Previous studies show that the chemical activity of MNP is determined mainly by electrostatic interactions, i.e. dipole-dipole (van der Waals forces) and ion-dipole interactions [29-31]. Donoracceptor (coordination) interactions, such as hydrogen bonds, are also involved in the adsorption of proteins, fats, carbohydrates, and water on the surface of the MNP [29-31, 36, 37]. In food systems, there are solvated nanoparticles (NP) of $\mathrm{Fe}_{3} \mathrm{O}_{4}$, which enter into hydrophilic contacts due to hydrogen bonds with water dipoles, molecules of proteins and polysaccharides (carbohydrates) containing hydrophilic groups $-\mathrm{C}-\mathrm{O}, \mathrm{C}-\mathrm{N}, \mathrm{O}-\mathrm{H}, \mathrm{S}-\mathrm{H}$ [29]. As a result, the stability of such systems as "protein + solvated MNP", "carbohydrate+solvated MNP" increases but the formation of hydrophobic bonds between the fragments of macromolecules is slowed down, which prevents their aggregation [30, 31].

Under the influence of $\mathrm{NP}$ of $\mathrm{Fe}_{3} \mathrm{O}_{4}$ macromolecular compounds (proteins, polysaccharides, higher fatty acids, and fats) undergo structural changes and form electrostatic complexes from NP of $\mathrm{Fe}_{3} \mathrm{O}_{4}$ [29-31] — quite stable structures such as "clusters", "clathrates", "cavities", and "supramolecular associates" [36, 37]. As a result, WRC and FRC of food systems increase.

Experimental confirmation of the interaction between the food nanoadditive based on double oxide of divalent and trivalent iron known as "Magnetofood" (FAM) and proteins, fats, polysaccharides, water

Fourier-transform infrared spectroscopy (FTIR). Table 1 and Table 2 show the results of IR spectroscopy. 
Comparison of wavenumbers of individual peaks in IR spectra of the

Table 1

"egg white+magnetofood" complex association and starting materials

(egg white and "Magnetofood', food additive known as FAM)

\begin{tabular}{|l|c|c|c|c|}
\hline \multirow{2}{*}{ Bond fluctuations } & \multicolumn{3}{|c|}{ Wavenumber position of maxima, $\mathbf{c m}^{\mathbf{- 1}}$} & \multirow{2}{*}{ Offset, $\mathbf{~ m}^{\mathbf{- 1}}$} \\
\cline { 2 - 4 } & egg white & FAM & "egg white+magnetofood" & \\
\hline $\begin{array}{l}v(\mathrm{O}-\mathrm{H}), \quad v(\mathrm{~N}-\mathrm{H})- \\
\text { Amide } A\end{array}$ & $3406 \pm 5$ & - & $3341 \pm 5$ & -65 \\
\hline$v_{\mathrm{as}}(\mathrm{C}-\mathrm{H})$ & $2927 \pm 4$ & - & $2927 \pm 4$ & 0 \\
\hline$v_{\mathrm{s}}(\mathrm{C}-\mathrm{H})$ & - & - & $2360 \pm 4 ; 2342 \pm 3$ & - \\
\hline$v(\mathrm{C}=\mathrm{O})-$ Amide I & $1653 \pm 3$ & - & $1642 \pm 3$ & -11 \\
\hline$\delta_{\mathrm{pl}}(\mathrm{N}-\mathrm{H})-$ Amide II & $1539 \pm 3$ & - & $1527 \pm 3$ & -12 \\
\hline$\delta_{\mathrm{pl}}(\mathrm{C}-\mathrm{H})$ & $1451 \pm 3$ & - & $1442 \pm 3$ & -9 \\
\hline$\delta_{\mathrm{pl}}(\mathrm{C}-\mathrm{C})$ & $1239 \pm 2$ & - & $1239 \pm 2$ & - \\
\hline$\delta_{\mathrm{pl}}(\mathrm{C}-\mathrm{C})$ & - & - & $1155 \pm 2$ & - \\
\hline$\delta_{\mathrm{epl}}(\mathrm{C}-\mathrm{C})$ & $1079 \pm 2$ & - & $1027 \pm 2$ & -52 \\
\hline$v(\mathrm{Fe}-\mathrm{O})$ & - & $532 \pm 2$ & $588 \pm 2$ & +56 \\
\hline
\end{tabular}

As can be seen from Table 1, the intense broadband with a maximum absorption $(3341 \pm 4) \mathrm{cm}^{-1}$, which is shifted in the complex associate to the low-frequency region of $\mathrm{cm}^{-}$ ${ }^{1}$ compared with the frequency of free $\mathrm{OH}$ groups and amide $\mathrm{A}(\mathrm{N}-\mathrm{H})(3406 \pm 4) \mathrm{cm}^{-1}$, indicates the participation of hydroxyl oxygen and amide nitrogen in the formation of coordination bonds with Fe atoms of FAM [36, 37].

Intense bands with maxima at $(2360 \pm 4) \mathrm{cm}^{-1}$ and $(2342 \pm 3) \mathrm{cm}^{-1}$, which are absent in the spectrum of egg white, are also observed. These peaks can be attributed to symmetric valence $\left(v_{\mathrm{s}}\right)$ oscillations of the $\mathrm{C}-\mathrm{H}$ bond. This is confirmed by the electrostatic hydrophobic interactions of aliphatic side chains of amino acid residues in "clathrates" and "cavities" that occur under the action of MNP [24, 25, 36, 37].

During the adsorption of egg white on the surface of the MNP, there is an offset of the absorption bands of the valence oscillations of amide $\mathrm{I} v(\mathrm{C}=\mathrm{O})$ and planar deformation oscillations of amide II $\delta_{\mathrm{pl}}(\mathrm{N}-\mathrm{H})$ to a lower frequency in the region: $v(\mathrm{C}=\mathrm{O})=(1642 \pm 3) \mathrm{cm}^{-}$ ${ }^{1} ; \delta_{\mathrm{pl}}(\mathrm{N}-\mathrm{H})=(1527 \pm 3) \mathrm{cm}^{-1}$, respectively $[25,26,36,37]$.

The absorption bands of planar and extraplanar deformation oscillations $\delta_{\mathrm{pl}}(\mathrm{C}-\mathrm{H})$ and $\delta_{\text {epl }}(C-C)=(1027 \pm 2) \mathrm{cm}^{-1}$ to a lower frequency in the region $\delta_{\mathrm{pl}}(\mathrm{C}-\mathrm{H})=(1442 \pm 3) \mathrm{cm}^{-1}$ and $\delta_{\text {epl }}(C-C)=(1027 \pm 2) \mathrm{cm}^{-1}$ respectively. A new absorption band of planar deformation oscillations $\delta_{\text {pl. }}(\mathrm{C}-\mathrm{C})(1155 \pm 2) \mathrm{cm}^{-1}$ is also observed. This confirms the electrostatic hydrophobic interactions of aliphatic and cyclic amino acid residues in the complex association [24, 27, 36, 37].

In the spectrum of pure FAM (Table 1), there is a line of absorption of the $\mathrm{Fe}-\mathrm{O}$ bond with a maximum at a value of $\sim 532 \mathrm{~cm}^{-1}$, which agrees well with the data presented in the scientific studies, that is $\sim 530 \mathrm{~cm}^{-1}[36,37]$. The offset of the maximum of the corresponding absorption band of $\mathrm{Fe}-\mathrm{O}$ valence oscillations in the "egg white+magnetofood" Complex to the region of $\sim 588 \mathrm{~cm}^{-1}$ is associated with the influence of surface egg protein molecules, their interference in the near-surface layer of $\mathrm{Fe}_{3} \mathrm{O}_{4}$ nanoparticles and chemical interaction with iron cations. Thus, the results of the studies confirm the formation of a complex between egg white and FAM [36, 37]. 
Comparison of IR spectra (Table 2) shows that the wave numbers of peaks differ in the spectra of the starting materials (starch, FAM) and the "starch+magnetofood" complex, indicating the chemical interaction in the carbohydrate-magnetofood model system.

Table 2

Comparison of wavenumbers of individual peaks in IR spectra of the "starch+magnetofood" complex association and starting materials (potato starch, FAM)

\begin{tabular}{|l|c|c|c|c|}
\hline \multirow{2}{*}{ Bond fluctuations } & \multicolumn{2}{|c|}{ Wavenumber position of maxima, $\mathbf{~ c m}^{-\mathbf{1}}$} & \multirow{2}{*}{ Offset, $\mathbf{~ c m}^{\mathbf{- 1}}$} \\
\cline { 2 - 4 } & starch & FAM & "starch+magnetofood" & \\
\hline$v(\mathrm{O}-\mathrm{H})$ & $3443 \pm 5$ & - & $3415 \pm 5$ & -28 \\
\hline$v_{\mathrm{as}}(\mathrm{C}-\mathrm{H})$ & $2927 \pm 4$ & - & $2917 \pm 4$ & -10 \\
\hline$v_{\mathrm{s}}(\mathrm{C}-\mathrm{H})$ & - & - & $2360 \pm 4 ; 2342 \pm 3$ & - \\
\hline$v(\mathrm{C}-\mathrm{O}-\mathrm{C})$ & $1653 \pm 3$ & - & $1640 \pm 3$ & -13 \\
\hline$\delta_{\mathrm{pl}}(\mathrm{C}-\mathrm{O}-\mathrm{C})$ & $1457 \pm 3$ & - & $1441 \pm 3$ & -16 \\
\hline$\delta_{\mathrm{pl}}(\mathrm{C}-\mathrm{C})$ & $1162 \pm 2$ & - & $1152 \pm 2$ & -10 \\
\hline$\delta_{\mathrm{pl}}(\mathrm{C}-\mathrm{C})$ & - & - & $1081 \pm 2 ; 1021 \pm 2$ & - \\
\hline$\delta_{\mathrm{epl}}(\mathrm{C}-\mathrm{C})$ & $982 \pm 2$ & & $922 \pm 2$ & -60 \\
\hline$\delta_{\mathrm{epl}}(\mathrm{C}-\mathrm{C})$ & $857 \pm 2$ & & $847 \pm 2$ & -10 \\
\hline$\delta_{\mathrm{epl}}(\mathrm{C}-\mathrm{C})$ & $763 \pm 2$ & & $753 \pm 2$ & -10 \\
\hline$v(\mathrm{Fe}-\mathrm{O})$ & - & $532 \pm 2$ & $589 \pm 2$ & +57 \\
\hline
\end{tabular}

As can be seen from Table 2, there is a shift of the intense band of free $\mathrm{OH}$ groups $(3443 \pm 5)$ $\mathrm{cm}^{-1}$ to the low-frequency region $(3415 \pm 5) \mathrm{cm}^{-1}$ in the spectrum of the "starch + magnetofood" complex - this indicates the participation of hydroxyl in the topic of hydrogen bonds and electrostatic coordination interactions with $\mathrm{Fe}$ atoms of $\mathrm{FAM}[36,37]$.

Shift of the peak of valence $v(\mathrm{C}-\mathrm{O}-\mathrm{C})$ by $(13 \pm 3) \mathrm{cm}^{-1}$ and planar deformation oscillations of $\delta_{\mathrm{pl}}(\mathrm{C}-\mathrm{O}-\mathrm{C})$ на $(16 \pm 3) \mathrm{cm}^{-1}$ to the low-frequency region compared to the experimental sample of starch indicates the presence of Coulomb and coordination interactions between Fe atoms of FAM and oxygen (ether, pyranose and hydroxyl) residues of D-glucopyranose [24, 25, 36, 37].

The appearance of new absorption bands in the region (700-1200) $\mathrm{cm}^{-1}$, which characterize the oscillations of the carbon skeleton, and an offset to the region of lower frequencies of some characteristic absorption bands $(\mathrm{C}-\mathrm{C})$ of bonds indicate the presence of hydrophobic and dispersive London forces between residues of glucopyranose [25, 26, 36, 37].

An offset of the maximum absorption of the $\mathrm{Fe}-\mathrm{O}$ bond to the high-frequency region by $(57 \pm 2)$ $\mathrm{cm}^{-1}$ compared with the experimental sample of pure FAM indicates the chemical interaction of iron cations of FAM with starch molecules [24, 27, 36, 37]. All this confirms the presence of chemical interaction in the "starch+magnetofood" complex association.

The study of chemisorption of linoleic acid and 1-linoleyl-2-oleoyl-3-linolenoylglycerol on the surface of FAM nanoparticles has been reported in previous studies [36, 37]. This indicates the chemical interaction of higher fatty acid and fat with $\mathrm{Fe}_{3} \mathrm{O}_{4}$ nanoparticles.

Energy dispersive spectroscopy (EDX). The X-ray spectra of all experimental samples displayed the peaks (Figure 1) of about $0.8 ; 6.3$ and $6.8 \mathrm{keV}$ associated with the absorption of the kinetic energy of electrons by the Fe atom. The spectra of MNP covered with protein, linoleic acid, oil and starch (Figure 1, b-e) contain two more peaks: about $0.27 \mathrm{keV}$ and $0.47 \mathrm{keV}$. These 
absorption bands belong to the $\mathrm{C}$ and $\mathrm{O}$ atoms [24, 26, 36, 37]. Moreover, the peak at $0.47 \mathrm{keV}$, which is characteristic of the $\mathrm{O}$ atom, also finds itself in the spectrum of pure FAM (Figure 1, a); and the peaks of about 0.3 and $1.2 \mathrm{keV}$ are associated with the absorption of kinetic energy by electrons of $\mathrm{N}$ and $\mathrm{S}$ atoms, respectively (Figure 1, b).

An EDX spectrum analysis of experimental samples (b, c, d, e) shows that $\mathrm{Fe}, \mathrm{O}$ and $\mathrm{C}(\mathrm{H}$ cannot be studied) and N and S (for sample b) are the main components in the system of "protein (fat, polysaccharide )+magnetofood".

Thus, systems with MNP have the following chemical composition: sample $a(\mathrm{FAM})-\mathrm{Fe}$ 75.5\%; O 24.5\%; sample b (MNP, coated with egg white) - Fe 44.7\%; O 26.9\%; C 21.4\%; N 5.9\%; S 1.1\%; sample c (MNP, coated with starch) - Fe 41.7\%; O 35.7\%; C 22.6\%; sample d (MNP, coated with linoleic acid) - Fe 45.6\%; O 34.7\%; C 19.7\%; sample e (MNP, coated with sunflower oil) $-\mathrm{Fe} 39.7 \%$; O $36.7 \%$; C $23.67 \%$.

Thus, the experimental samples $(b-e)$ obtain a new chemical element $(\mathrm{C})$, and the experimental sample $(b)$ acquire two more elements $(\mathrm{N}$ and $\mathrm{S}$ ), which are absent in pure FAM (sample a). The result indicates that FAM nanoparticles were successfully obtained (sample a) and the main substances of food systems such as proteins, fats, and polysaccharides (samples $b-e$ ) are chemisorbed on FAM particles.

Mass fraction of bound and free moisture. The experimental data presented in Figure 2 show that $1 / 5$ of the water in solvated FAM is chemically bound moisture; $1 / 2-$ bound moisture; $1 / 10$ - free moisture and 1/2 - free, osmotic (swelling water) and physicomechanical of the total amount of water.

The studies indicate the high hydration capacity of food nanoadditives based on double oxide of divalent and trivalent iron "Magnetofood" (FAM), which can improve the functional and technological properties of heterogeneous dispersed systems in food production technologies. 
Intensivity, I, r.u.
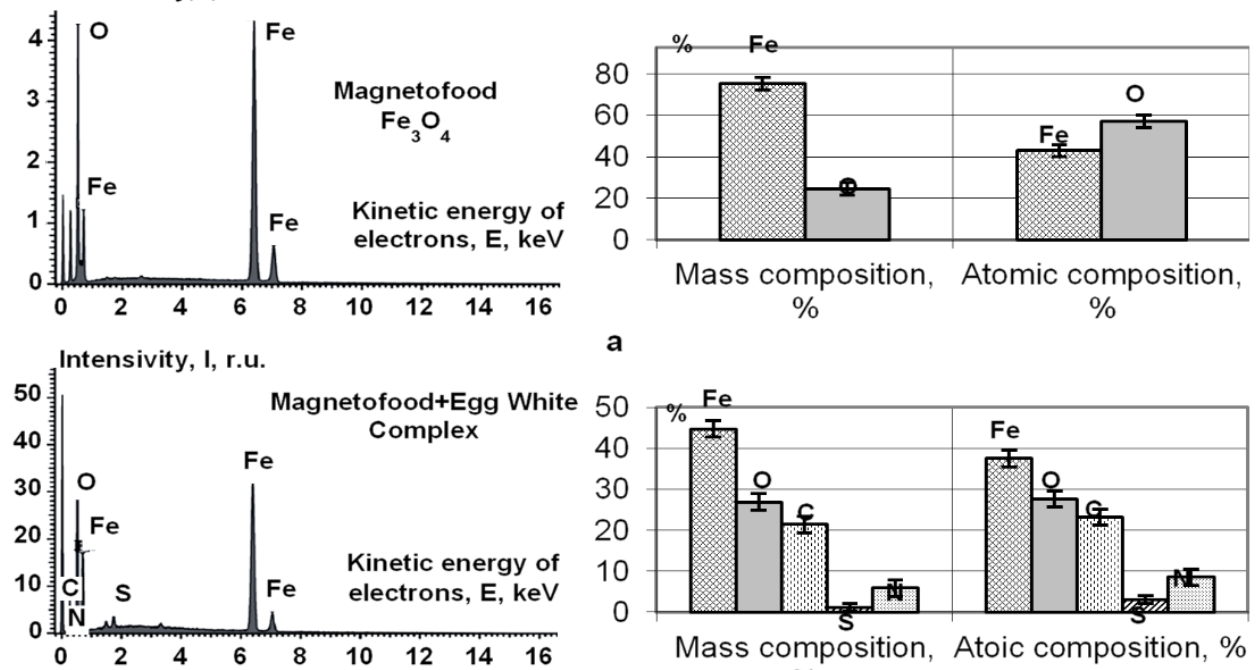

a
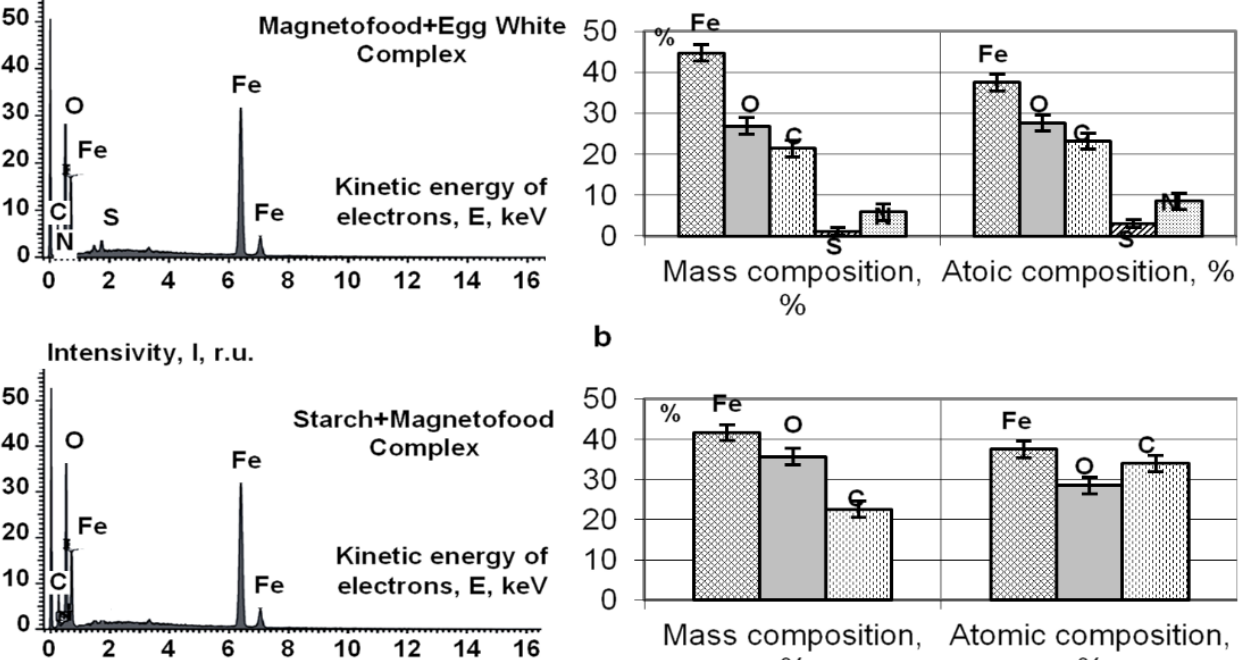

b
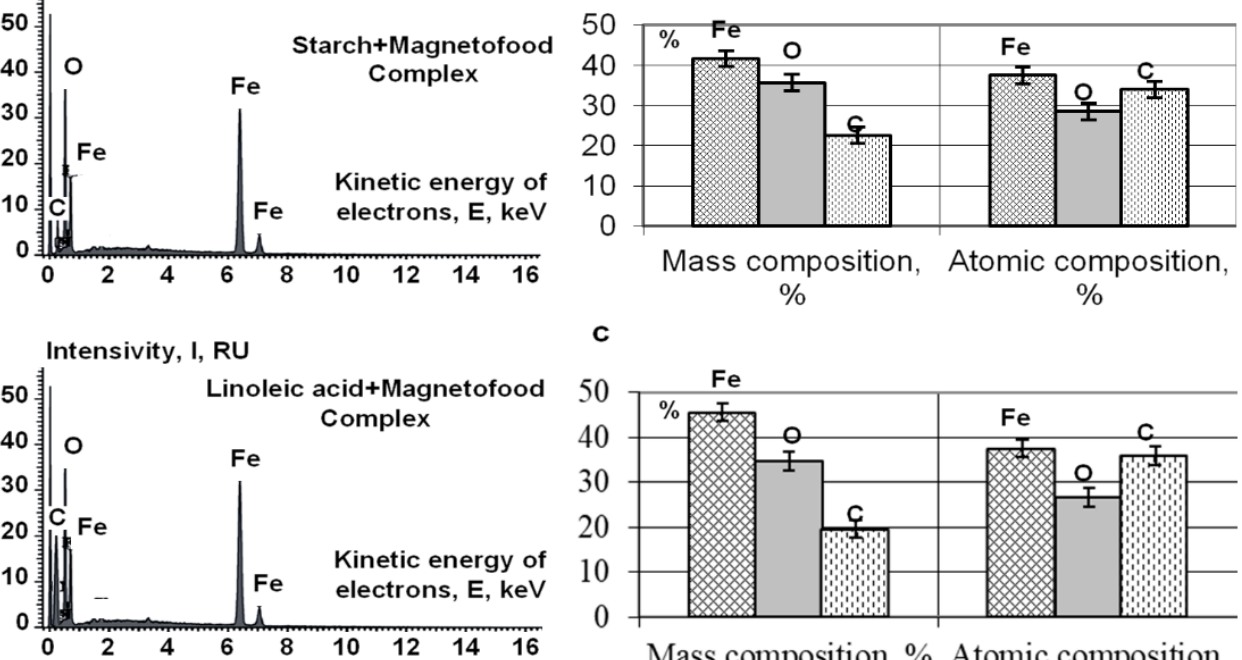

C

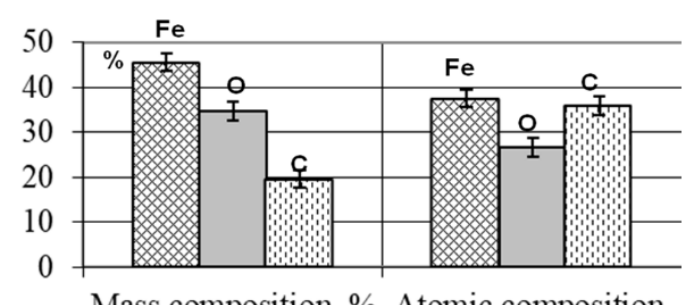

Mass composition, \% Atomic composition,

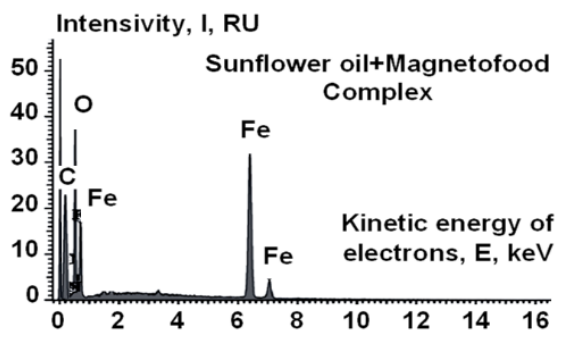

d

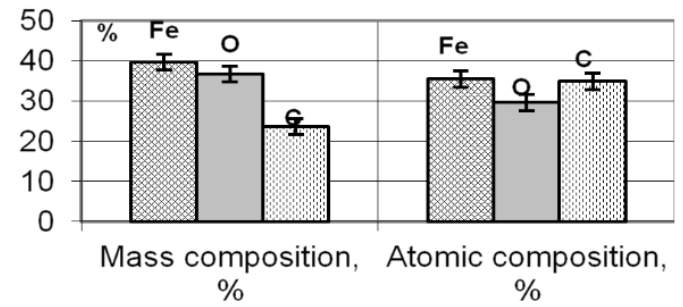

Figure 1. EDX-spectra of model systems with FAM:

a - FAM; b-egg white+magnetofood; $c$ - starch+magnetofood; $d$ - linoleic acid+magnetofood; d - sunflower oil+magnetofood 

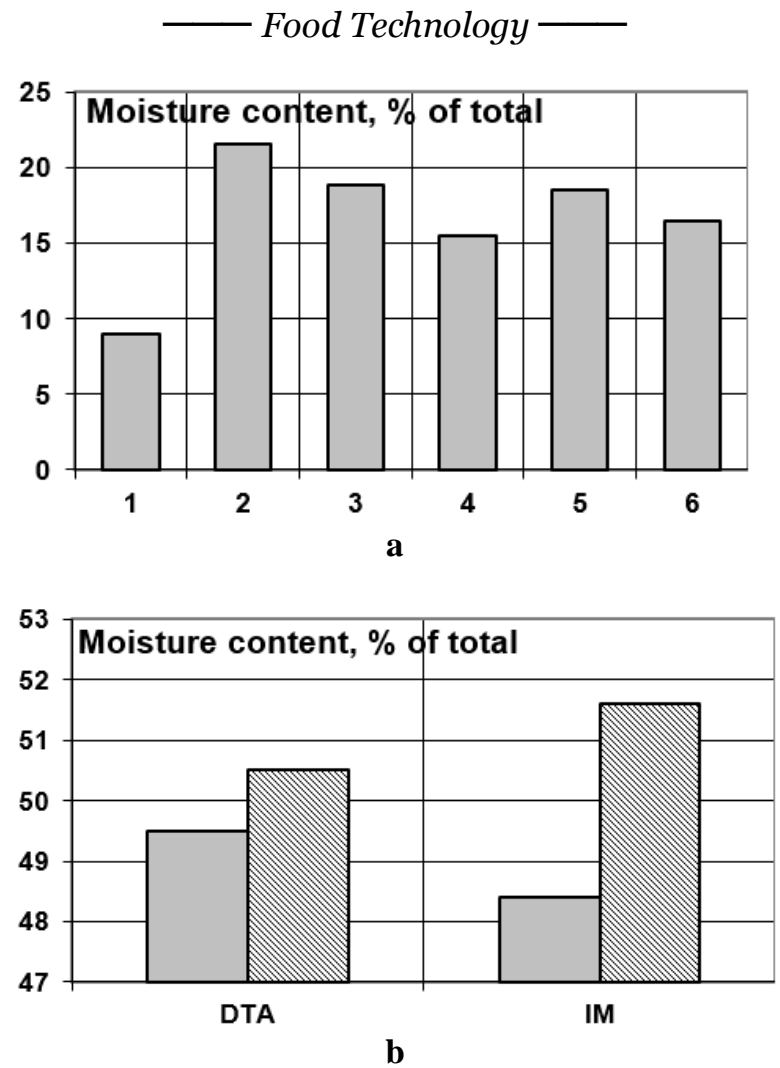

Figure 2. The distribution of water by types of bonds in FAM after swelling determined by the methods: a - DTA ( 1 - free moisture; 2 - physically and mechanically bound; 3 - osmotically

bound (swelling water); 4 - adsorption bound (polymolecular); 5 - adsorption bound

(monomolecular); 6 - chemically bound); $b$ - IM and the method of DTA

- amount of free, osmotic and physico-mechanical moisture; $\square-$ amount of bound moisture)

\section{Conclusions}

1. The ability of nanoparticles of food additive $\mathrm{Fe}_{3} \mathrm{O}_{4}$ was noted to form supramolecular associations with macromolecular compounds of food systems, which promote the binding and retention of water and fat.

2. The interaction of macromolecular compounds (starch, egg white, higher fatty acid, fat) and water with nanoparticles of FAM was studied:

- Fourier-transform infrared spectroscopy proved chemosorption of macromolecular compounds (starch, egg white, higher fatty acid, triglyceride) on the surface of NP food additive $\mathrm{Fe}_{3} \mathrm{O}_{4}$ : a shift of the maximum of $\mathrm{Fe}-\mathrm{O}$ bond absorption to the highfrequency region by $(57 \pm 2) \mathrm{cm}^{-1}$ in comparison with the experimental sample of pure FAM indicates the chemical interaction of FAM iron cations with molecules of macromolecular compounds (starch, egg white, fat, higher fatty acids); the spectrum of macromolecular compound+magnetofood Complexes demonstrates an offset of the intense band of free $\mathrm{OH}$ groups $(3443 \pm 5) \mathrm{cm}^{-1}$ in the low-frequency region by $(28 \pm 2)$ 
$\mathrm{cm}^{-1}$, which indicates the participation of hydroxyl in the topic of hydrogen bonds and electrostatic coordination interactions with Fe atoms of FAM. The appearance of new absorption bands in the region of (700-1200) $\mathrm{cm}^{-1}$, which characterize the oscillations of the carbon skeleton, and an offset in the region of lower frequencies of some characteristic bands that absorb $(\mathrm{C}-\mathrm{C})$ bonds indicate the presence of hydrophobic and dispersion interactions between residues of glucopyranose, aliphatic and cyclic amino acid residues and aliphatic triglyceride residues;

- Energy dispersion X-ray spectroscopy determined the chemical composition of model systems of macromolecular compounds with food additive $\mathrm{Fe}_{3} \mathrm{O}_{4}$ (FAM): sample a (FAM) - Fe 75.5\%; O 24.5\%; sample b (MNP, coated with egg white) - Fe 44.7\%; O 26.9\%; C 21.4\%; N 5.9\%; S 1.1\%; sample c (MNP, coated with starch) - Fe 41.7\%; O 35.7\%; C 22.6\%; sample d (MNP, coated with linoleic acid) - Fe 45.6\%; O 34.7\%; C 19.7\%; sample e (MNP, coated with sunflower oil) - Fe 39.7\%; O 36.7\%; C $23.67 \%$. That is, the compounds (samples $b-e$ ) are chemisorbed on the particles of $\mathrm{Fe}_{3} \mathrm{O}_{4}$ food additive. And the band absorbing the $\mathrm{C}$ atom, which appeared in samples $b-e$, confirms the process of adsorption and chemical interaction between the particles of $\mathrm{Fe}_{3} \mathrm{O}_{4}$ food additive and macromolecular compounds;

- The ratio of bound and free moisture in solvated FAM was established using the indicator method and differential thermal analysis: 1/5 of water falls on chemically bound moisture; $1 / 2$ - bound moisture; $1 / 10$ - free moisture and 1/2 part - free, osmotic (swelling water) and physico-mechanical water of the total amount.

\section{Recommendations}

The studies show the water and fat-retaining ability of food nanoadditives based on double oxide of divalent and trivalent iron known as "Magnetofood" (FAM), which can improve the functional and technological properties of polyphase systems, improve quality and extend the shelf life of finished products in food production technologies.

Knowledge of mechanisms: interaction of FAM nanoparticles with proteins, fats, and carbohydrates; binding and retention of water and fat by raw materials will allow the rational use of new types of food raw materials and predict the behaviour of raw ingredients in food products with a heterogeneous dispersed structure.

\section{References}

1. Maforimbo E., Skurray G.R., Nguyen M.L. (2007), Evaluation of 1-ascorbic acid oxidation on $\mathrm{SH}$ concentration in soy-wheat composite dough during resting period, Food Sci. and Technol., 40(2), pp. 338-343.

2. Rosell C.M., Aja S., Bean S., Lookhart (2003), Wheat flour proteins as affected by transglutaminase and glucose oxidase, Cereal Chem., 80(1), pp. 52-55.

3. Chugunova O.V.. Pastushkova E.V. (2015). Modelirovaniye organolepticheskikh pokazateley khleba s rastitelnymi dobavkami. Vestnik YuUrGU. Seriya «Pishchevyye $i$ biotekhnologii». Ekaterinburg: Izdatelskiy tsentr YuUrGU, 3(4), pp. 80-87.

4. Tamazova S.Iu., Lisovoi V.V., Pershakova T.V., Kazimirova M.A. (2016), Pishchevye dobavki na osnove rastitelnogo syria, primeniaemye $\mathrm{v}$ proizvodstve khlebobulochnykh i muchnikh konditerskikh izdelii, Politematicheskii setevoi elektronnyi nauchnyi zhurnal KubGAU, 122 (08), pp. 1-8. 


\section{- Food Technology -}

5. Rosliakov Iu.F., Vershinina O.L., Gonchar V.V. (2016), Nauchnye razrabotki dlia khlebopekarnoi i konditerskoi otraslei, Tekhnologii pishchevoi i pererabatyvaiushchei promyshlennosti, APK-produkty zdorovogo pitaniia, 6, pp. 1-6.

6. Rosliakov Iu.F., Vershinina O.L., Gonchar V.V. (2010), Perspektivnye issledovaniia tekhnologii khlebobulochnykh izdelii funktsionalnogo naznacheniia, Izvestiia vuzov, Pishchevaia tekhnologiia, 1, pp. 123-125.

7. Gorshunova K.D., Semenova P.A., Bessonov V.V. (2012), Vzaimodeistvie gidrokolloidov i vodorastvorimykh vitaminov pri konstruirovanii obogashchennykh pishchevykh produktov, Pishchevaia promyshlennost, 11, pp. 46-49.

8. Filips G.O., Viliams P.A. (2006), Spravochnik po gidrokolloidam, per. s angl., pod red. Kochetkovoi A.A. i Sarafanovoi L.A., Sankt-Peterburg.

9. (2013), Tsitrusovye volokna Herbacel AQ Plus - tip N: spetsifikatsii dlia pishchevykh dobavok i retseptury, Available at: http://specin.ru.

10. Domoroshchenkova M.L., Demianenko T.F., Kamysheva I.M. (2007), Issledovanie funktsionalno-tekhnologicheskikh svoistv izoliatov soevykh belkov, Maslozhirovaia promyshlennost, 4, p. 24-28.

11. Renziaeva T.V., Pozniakovskii V.M. (2009), Vodouderzhivaiushchaia sposobnost syria i pishchevykh dobavok $\mathrm{v}$ proizvodstve muchnykh konditerskikh izdelii, Khranenie i pererabotka selkhozsyria, 8, p. 35-38.

12. Renziaeva T.V., Tuboltseva A.S., Ponkratova E.K., Lugovaia A. V., Kazantseva, A. V. (2014), Funktsionalno-tekhnologicheskie svoistva poroshkoobraznogo syria i pishchevykh dobavok v proizvodstve konditerskikh izdelii, Tekhnika i tekhnologiia pishchevykh proizvodstv, 4, p. 43-49.

13. Buldakov A. (2008), Pishchevye dobavki: Spravochnik., Sankt-Peterburg.

14. Drobot V.I. (2008), Ispolzovanie netraditsionnogo syria v khlebopekarnoi promyshlennosti, Urozhai, Kyiv.

15. Martins Z. E., Pinho O., Ferreira I.M.P.L.V.O. (2017), Food industry by-products used as functional ingredients of bakery products, Trends in Food Science \& Technology, 67, pp. 106-128, DOI: 10.1016/j.tifs.2017.07.

16. Lai W.T., Khong N.M.H., Lim S.S., Hee Y.Y., Sim B.I., Lau K.Y., Lai O.M. (2017), A review: Modified agricultural by-products for the development and fortification of food products and nutraceuticals, Trends in Food Science \& Technology, 59, pp. 148-157.

17. Bharath Kumar S., Prabhasankar P. (2014), Low glycemic index ingredients and modified starches in wheat based food processing: A review, Trends in Food Science \& Technology, 35(1), pp. 32-41.

18. Ngemakwe P.N., Le Roes-Hill M., Jideani V. (2014), Advances in gluten-free bread technology, Food Science and Technology International, 21(4), pp. 256-276.

19. Bird L.G., Pilkington C.L., Saputra A., Serventi L. (2017), Products of chickpea processing as texture improvers in gluten-free bread, Food Science and Technology International, 23(8), pp. 690-698.

20. García-Segovia P., Pagán-Moreno M.J., Lara I.F., Martínez-Monzó J. (2017), Effect of microalgae incorporation on physicochemical and textural properties in wheat bread formulation, Food Science and Technology International, 23 (5), pp. 437-447.

21. Boubaker M., Omri A.E., Blecker C., Bouzouita N. (2016), Fibre concentrate from artichoke (Cynara scolymus L.) stem by-products: Characterization and application as a bakery product ingredient, Food Science and Technology International, 22(8), pp. 759-768. 
22. Ramachandraiah K., Choi M.-J., Hong G.-P. (2018), Micro- and nanoscaled materials for strategy-based applications in innovative livestock products: A review, Trends in Food Science \& Technology, 71, pp. 25-35.

23. Iliukha N.G., Barsova Z.V., Kovalenko V.A., Tsikhanovskaia I.V. (2010), Tekhnologiia proizvodstva i pokazateli kachestva pishchevoi dobavki na osnove magnetita, Vostochno-Evropeiskii zhurnal peredovykh tekhnologii, 6/10(48), pp. 3235.

24. Drmota A., Kosak A., Znidarsik A. (2008), A mechanism for the adsorption of carboxylic acids onto the surface of magnetic nanoparticles, Materials and technology, Ljubljana, Slovenia, 42, pp. 79-83.

25. Mahdavi M., Ahmad M.B., Haron M.J., Namvar F., Nadi B., Ab Rahman M.Z., Amin J. (2013), Synthesis, Surface Modification and Characterisation of Biocompatible Magnetic Iron Oxide Nanoparticles for Biomedical Applications, Molecules, 18, pp. 7533-7548.

26. Zhang L., He R., Gu H.-C. (2006), Oleic acid coating on the monodisperse magnetite nanoparticles, Applied Surface Science, APSUSC-14301, 7, pp. 1-7.

27. Chernyshova I., Ponnurangam S., Somasundaran P. (2011), Adsorption of Fatty Acids on Iron (Hydr)oxides from Aqueous Solutions, Langmuir, 27(16), pp. 10007-10018.

28. Tsykhanovska I., Alexandrov A., Evlash V., Lazareva T., Svidlo K., Gontar T. (2018), Investigation of the moisture-retaining power of rye-wheat gluten and flour with polyfunctional food supplement "Magnetofood", "Eureka: Life Sciences", Estonia,Tallinn, 2/14(2), pp. 67-76, DOI: 10.21303/2504-5695.2018.00611.

29. Tsykhanovska I., Evlash V., Alexandrov A., Lazareva T., Svidlo K., Gontar T., Yurchenko L., Pavlotska L. (2018), Substantiation of the mechanism of interaction between biopolymers of rye-and-wheat flour and the nanoparticles of the "Magnetofood" food additive in order to improve moisture-retaining capacity of Dough, Eastern-European Journal of Enterprise Technologies, 2/11(92), pp. 70-80.

30. Tsykhanovska I., Evlash V., Alexandrov A., Lazareva T., Bryzytska O. (2018), Substantiation of the interaction between the lipo- and glucoproteids of rye-wheat flour and nanoparticles of the food additive "Magnetofood", Eastern-European Journal of Enterprise Technologies, 4/11(94), pp. 61-68.

31. Tsykhanovska I., Evlash V., Alexandrov A., Lazareva T., Yevlash T. (2018), Substantiation of the mechanism of interaction of between the carbohydrates of ryewheat flour and nanoparticles of the polyfunctional food additive "Magnetofood", Eastern-European Journal of Enterprise Technologies, 3/11(93), pp. 59-68.

32. Levitin E.Ja., Vedernikova I.A., Tsikhanovskaia I.V. i dr. (2007), Issledovanie elektropoverkhnostnykh svoistv magnetitovykh dispersnykh sistem na vodnoi osnove, Vostochno-Evropeiskii zhurnal peredovykh tekhnologii, 3/4(27), pp. 16-18.

33. Tsykhanovska I.V., Yevlash V.V., Lazarieva T.A., Shynhisov A.U. (2019), Doslidzhennia strukturno-mekhanichnykh pokaznykiv ta pinoutvorennia zefirnykh mas z riznymy strukturoutvoriuvachamy pry vvedenni v retsepturu kharchovoi dobavky "Mahnetofud", Pratsi TDAU. Tekhnichni nauky. Melitopol, 2(19), pp. 168-189.

34. Aleksandrov O.V., Tsykhanovska I.V., Barsova Z.V., Dudenko N.V., Pavlotska L.F., Skurikhina L.A. (2015), Oderzhannia ta doslidzhennia vlastyvostei biolohichnoaktyvnykh dobavok na osnovi lipido-mahnetytovykh suspenzii, Povnotsenne kharchuvannia: innovatsiini aspekty tekhnolohii, enerhoefektyvnoho vyrobnytstva, zberihannia ta marketynhu: kolektyvna monohrafiia, Kharkiv, pp. 138-167.

35. Tsykhanovska I.V., Aleksandrov O.V., Lazarieva T.A., Hontar T.B., Pavlotska L.F. (2016), Vykorystannia zhyro-mahnetytovoi suspenzii dlia pidvyshchennia kharchovoi 


\section{- Food Technology -}

tsinnosti tsukerok "Sukhofrukty $\mathrm{v}$ shokoladi", zbahachenykh zalizovmisnoiu kharchovoiu dobavkoiu, Povnotsinne kharchuvannia: innovatsiini aspekty tekhnolohii, enerhoefektyvnoho vyrobnytstva, zberihannia ta marketynhu: kolektyvna monohrafiia. Kharkiv, pp. 143-170.

36. Tsykhanovska I., Evlash V., Alexandrov A., Gontar T. (2018), Mechanism of fatbinding and fat-contenting of the nanoparticles of a food supplement on the basis of double oxide of two- and trivalent iron, Ukrainian Food Journal, 7(4), pp. 702-715.

37. Iryna Tsykhanovska, Victoria Evlash, Alexandr Alexandrov, Tatyana Gontar, Daniil Shmatkov (2019), The study of the interaction mechanism of linoleic acid and 1linoleyl-2-oleoyl-3-linolenoyl-glycerol with $\mathrm{Fe}_{3} \mathrm{O}_{4}$ nanoparticles, Chemistry \& chemical technology. Chemistry, Lviv, 13(3), pp. 303-316, DOI: 10.23939/chcht13. 03.303.

38. Tarasiuk N.L., Barsova Z.V., Tsykhanovska I.V. (2012), Tekhnolohiia otrymannia oliino-mahnetytovыkh suspenzii, Khimichni Karazinski chytannia - 2012 (KhKCh12): tezy IKh Vseukr. nauk. konf., 23-26 kvitnia 2012 roku, pp. 326-327.

39. Tsykhanovska I., Alexandrov A., Gontar T., Kokodiy N., Dotsenko N. (2016), Stability and morphological characteristics of lipid-magnetite suspensions, Eureka: Life Sciences, 3(3), pp. 14-25.

40. Hansen S.F., Heggelund L.R., Besora P.R., Mackevica A., Boldrin A., Baun A. (2016), Nanoproducts - what is actually available to European consumers? Environmental Science: Nano, 1, pp. 1-8.

41. Thiruvengadam M., Rajakumar G., Chung M. (2018), Nanotechnology: current uses and future applications in the food industry, 3 Biotech, 8(1), pp. 74-83.

42. Iurchak V.G., Berzina N.I., Shmarovoz V.M., Prishchepa M.P. (1989), Opredelenie sviazannoi vody indikatornym metodom $\mathrm{v}$ khlebopekarnom proizvodstve, Izvestiia vuzov, Pishchevaia tekhnologiia, 4, p. 78-80.

43. Nilova L.P., Kalinina I.V., Naumenko N.V. (2013), Metod differentsialnotermicheskogo analiza v otsenke kachestva pishchevykh produktov, Vestnik IuUrGU, Pishchevye i biotekhnologii, 1(1), p. 43-49. 